rounded up into whitish opaque nodules, regaining a definite shape after approximately $12 \mathrm{hr}$. in vitro. The nodules increased in size during the cultivation period, and, in addition, there was a peripheral outgrowth of clearly visible fibroblasts, growing in a radial pattern.

A similar experiment was carried out with cartilage from 18-day rat embryos. The tibiæ and femora were fragmented and treated in exactly the same way as described previously. As there appeared to be no difference between the survival of 17 - and 18.day embryonic cartilage, or between tibiæ and femora, the results were combined and are shown in Table 1 .

Table 1. RESULTS OBTAINED AFTER SLOWLY FREEZING EMBRYONIC RAT CARTILAGE FROM 17-DAY AND 18-DAY THBIAE AND FEMORA TO - $79^{\circ} \mathrm{C}$. THK CARTILAGE WAS PRETRRATED WITH TRYPSIN aND

\begin{tabular}{|l|c|c|c|}
\hline & Killed & Survived & Total \\
\hline Trozen & 4 & 10 & 14 \\
Unfrozen & 1 & 9 & 10 \\
Total & 5 & 19 & $\mathbf{2 4}$ \\
\hline
\end{tabular}

The probability of these results, or more extreme ones, arising from chance, was calculated using Fisher's exact method ${ }^{10}$. The probability was found to be $P=0.566$; thus, although there is a suggestion that the frozen cultures had a greater mortality than the non-frozen cultures, on the data obtained, this is nowhere near significant at the conventional $P=0.05$ level.

Histological examination of the explants which survived the experimental treatments revealed that both the rounded epiphyseal and the hypertrophic diaphyseal cells survived the freezing. The morphology of the cells was normal; and when the sections were stained with toluidine blue, the charac. teristic metachromasia of the matrix was seen.

I wish to acknowledge financial assistance from the Medical Research Council, in a grant made to the Department of Physiology, Royal Veterinary College.

Department of Physiology, Susan Heyner*

Royal Veterinary College, London, N.W.1.

* Present address: Wistar Institute of Anatomy and Biology, Philadephia, Pa.

'Polge, C., Smith, A. U., and Parkes, A. S., Nature, 164, 666 (1949). ${ }^{2}$ Curran, R. C., and Gibson, T., Proc. Roy. Soc., B, 144, 572 (1955).

${ }^{3}$ Biggers, J. D., Experientia, 13, 483 (1957).

4 Heyner, S., J. Exp. Zool. (in the press).

${ }^{\circ}$ Biggers, J. D., Gwatkin, R. B. L., and Heyner, S., Exp. Cell. Res. (in the press).

${ }^{8}$ Fell, H. B., and Robison, R., Biochem. J., 23, 767 (1929)

'Chen, J. M., Exp. Cell Res., 7, 518 (1954).

8 Smith, A. U., Exp. Cell Res., 3, 574 (1952).

- Moscona, A., and Moscona, H., J. Anat., 86, 287 (1952).

${ }^{10}$ Fisher, R. A., Statisticat Methods for Research Workers, tenth ed. (Oliver and Boyd, Edinburgh, 1948).

\section{Temperature Coefficient of Endodiurnal Leaf Movements in Phaseolus}

ThE effect of temperature on the length of cycle of endodiurnal rhythms has been investigated in various processes in plants and animals. It was repeatedly found that within the physiological range the length of cycle is independent of temperature ${ }^{1-3}$. Several other endodiurnal rhythms, however, showed various temperature coefficients between 0.8 and $>3$ (refs. 4-6). Went ${ }^{7,8}$ reported a temperature coefficient in leaf movements of Phaseolus of 1.2 which is in agreement with early observations of Bünning ${ }^{9}$. Went, however, does not state under what conditions his plants were grown before measuring the cycle. As I have pointed out ${ }^{10}$, the external conditions under which the seedlings are grown will determine the response. Etiolated plants, grown at 15, 20 and $25^{\circ} \mathrm{C}$., showed a constant cycle-length of $28 \cdot 0-28 \cdot 3 \mathrm{hr}$. When the plants were grown in the greenhouse and then transferred to constant conditions, a $Q_{10}$ of 1.2 was observed for the first two cycles; the $Q_{10}$ changed in the subsequent cycles to 0.9 , thus revealing a temperature-compensating mechanism.

Went's statement" that my investigations "did not give any temperature effects on the cycle length but showed a constant 24 -hr. cycle over a whole range of temperatures" is erroneous. I did not report a 24-hr. cycle in leaf movements. Went implies that a 24-hr. cycle of smoke and fog governed the leaf movements in my investigations. This assunption cannot be maintained since a cycle-length of $28 \mathrm{hr}$. was observed in etiolated plants. Furthermore, greenhouse-grown plants, measured at $20^{\circ} \mathrm{C}$. at constant darkness, showed over five days a constant cyclelength of $26 \cdot 1-26 \cdot 7 \mathrm{hr}$. This finding by Lörcher ${ }^{11}$, who used the same facilities as mine, does not reveal effects of external factors operating in regulating the Phaseolus clock.

Increased variability in the cycle-length under constant conditions ${ }^{10}$ also indicates that the leaf movements were not controlled by external factors.

I showed that greenhouse-grown plants exhibit after transfer to constant conditions in the first two cycles after the transfer a $Q_{10}$ of 1.2 the same coefficient as found by Bünning and Went. Whether or not the length of cycle is altered by temperature, however, is largely dependent on the pretreatment of the seedlings.

\section{Franz-Josef Leinweber}

McCollum-Pratt Institute,

Johns Hopkins University,

Baltimore 18, Maryland.

'Ball, N. G., and Dyke, I. J., J. Exp. Bot., 5, 421 (1954).

'Kalmus, H., Z vergl. Physiol., Abt. C, 20, 405 (1934).

${ }^{3}$ Brown, F. A., and Webb, H. M., Physiol. Zool., 21, 371 (1948).

4 Bühnemann, F., Z. Naturforsch., 10, b, 305 (1955).

"Uebelmesser, E.-R., Arch. Mikrobiol., 20, 1 (1954).

- Kalmus, H., Z. vergl. Physiol., Abt. C, 25, 494 (1938).

${ }^{7}$ Went, F. W., Ser. B. de l' V.I.S.B. Colloque International sur le Photo-thermopériodism, Parma, Publ. 34 (1957).

${ }^{8}$ Went, F. W., Amer. A880c. Adv. Sci., Publ. No. 55, 551 (1959).

• Bünning, E., Jahrb. wiss. Bot., 75, 439 (1932).

${ }^{10}$ Leinweber, F.-J., $Z$. Bot., 44, 337 (1956).

${ }^{11}$ Lörcher, L., $Z$. Bot., 46, 209 (1958).

\section{The Northern Rockling in the Clyde Sea Area}

ON August 15, 1960, a northern rockling, Ciliata septentrionalis (Collett 1875), was caught in the Clyde Sea area. The fish was caught at a depth of 30-40 fathoms in a small mesh cover that had been fitted over the cod end of a trawl used by R.V. Calanus. It is $10.6 \mathrm{~cm}$. in length and agrees closely with the descriptions of Smitt ${ }^{1}$ and Schnackenback ${ }^{2}$.

This is the first record of Ciliata septentrionalis from Britain. Elsowhere it has been recorded in Norway between $70^{\circ} 13^{\prime} \mathrm{N}$. and Bergen ${ }^{3}$ and from south Greenland ${ }^{4}$. I have previously found two specimens in a jar in the Sales Department here, but there was no record of when the fish were preserved, who preserved them or where they came from. However, 